\title{
Genitogluteal porokeratosis: a clinical review
}

This article was published in the following Dove Press journal:

Clinical, Cosmetic and Investigational Dermatology

\author{
Rajiv Joshi' \\ Khushboo Minni² \\ 'Department of Dermatology, P. D. \\ Hinduja Hospital, Mumbai, India; \\ ${ }^{2}$ Department of Dermatology, Mumbai \\ Port Trust Hospital, Mumbai, India
}

Correspondence: Rajiv Joshi

P. D. Hinduja Hospital, Veer Savarkar Marg, Mahim, Mumbai 400020, India

Tel+9l 9322276418

Email rsjdr@rediffmail.com

\begin{abstract}
Porokeratosis is an uncommon disorder of keratinization that presents with keratotic papules or annular plaques that expand centrifugally with a thread-like elevated border. A distinctive histologic structure, the cornoid lamella, is diagnostic of this disorder and consists of a column of parakeratosis with the absence of the granular layer and dyskeratotic cells in the upper spinous zone. Porokeratosis confined to the genitogluteal region is rare and may be subclassified into three types, namely, classical porokeratosis on the genital region, ptychotropic porokeratosis most often seen in the natal cleft and buttocks and penoscrotal porokeratosis that is seen on the penis and adjacent scrotal skin in young men in their third decade of life. Genitogluteal porokeratosis is usually pruritic and may be undiagnosed for several years as it does not resemble classical porokeratosis in many cases; however, a biopsy is diagnostic. In general, response of genital porokeratosis to any modality of treatment is disappointing. No malignant changes have hereto been reported in porokeratosis restricted to the genitogluteal region.
\end{abstract}

Keywords: genital porokeratosis, ptychotropic porokeratosis, penoscrotal porokeratosis

\section{Introduction}

Porokeratosis was first described by Isidor Neuman in $1875^{1}$ but has been eponymically linked with Vittorio Mibelli, an Italian dermatologist, who, in 1893, named it porokeratosis because of the involvement of eccrine ostia in his case. ${ }^{2}$ It is an uncommon disorder of keratinization of unknown etiology and unpredictable course and presents itself as a keratotic papule or annular plaque with a thread-like elevated border that expands centrifugally ${ }^{3}$ and has been likened to the Great Wall of China with a ridge and moat on its summit.

Since the description of the classical plaque type of porokeratosis of Mibelli, several other clinical forms of porokeratosis have been described, namely, disseminated actinic and non-actinic superficial porokeratosis, porokeratosis in linear arrangement, palmoplantar porokeratosis and punctate porokeratosis. Other less common forms described in literature are facial porokeratosis, giant porokeratosis, reticulate porokeratosis, eruptive pruritic papular porokeratosis and so on.

It is extremely rare for different clinical variants to occur in the same individual, but cases have been described where typical porokeratosis of Mibelli may coexist with the disseminated superficial form, linear and hypertrophic verrucous forms. ${ }^{4}$

Histologically, the hallmark of all porokeratoses is the cornoid lamella, which is a column of parakeratosis that is often seen to bend inward toward the center of the lesion with the absence of the granular layer at its base. Of great significance diagnostically are few dyskeratotic keratinocytes just beneath in the upper spinous zone. The cornoid lamellae may be few in number as in porokeratosis of Mibelli where they are seen typically one on either side of the lesion or multiple as seen in penoscrotal 
porokeratosis and porokeratosis ptychotropica. They also arise from adnexal structures, both follicular infundibula and eccrine ostia as in porokeratotic adnexal ostial nevi. ${ }^{5}$

Presence of cornoid lamellae without typical clinical appearance of annular papules or plaques has been suggested to be an epidermal reaction pattern that may be steroid responsive $^{6}$ or long-standing. ${ }^{7}$

Involvement of the genital region and adjacent areas (buttocks, perineum, groin and proximal thighs) may occur as part of generalized porokeratosis occurring elsewhere on the body; ${ }^{8-12}$ however, porokeratosis localized to the genitogluteal region is rare and very few cases have been described in literature.

The following is a clinical review of genitogluteal porokeratosis, where lesions occur only in the genitalia and/ or anal and gluteal region. A MEDLINE database search using the keywords genital, scrotal, anal, gluteal and vulval porokeratosis was done and the data collected were reviewed.

\section{Genitogluteal porokeratosis}

The first case of porokeratosis localized to the genital areas was probably described by Helfman and Poulos in $1985 .{ }^{13}$ They described a young man with chronic persistent reticulated dermatosis involving the groin, genitals and thighs that was refractory to therapy. Biopsy revealed multiple cornoid lamellae consistent with porokeratosis.

Since then, there have been no more than 50 reports in the literature. Porokeratosis restricted to male and female genitalia have been described as scrotal, penoscrotal, penile, vulval and genito-cruro-anal and those restricted to buttocks as gluteal according to the site of involvement encompassing the term "genitogluteal porokeratosis."

All cases described under the term genitogluteal porokeratosis may broadly be divided into three groups, namely:

1. classical porokeratosis restricted to the genital region,

2. ptychotropic porokeratosis and

3. penoscrotal porokeratosis

All these three groups have in common the presence of cornoid lamellae, which is a diagnostic and unifying factor to include them under the broader rubric of porokeratosis. They differ in morphologic appearance of the lesions, sites involved and age of presentation.

\section{Classical porokeratosis restricted to the genital region}

Table 1 presents a review of cases of genital porokeratosis.

Classical porokeratosis of Mibelli may be localized to the genital region and while it remains a rare entity, a possible increased incidence may occur in Asian and AfricanAmerican populations. ${ }^{14-16}$ The pathogenesis of this entity remains uncertain, and both genetic and environmental factors have been implicated. The majority of patients reported have been middle-aged males who have had the lesions for over a year before presenting to the dermatologist. The mean age at initial diagnosis is 39 years (range 22-61 years). The lesions most commonly affect the scrotum, penis and buttocks and adjacent thighs. Lesions on glans penis have been described, and Porter et al reported a case involving the external urethral meatus. ${ }^{17}$

Most lesions are typical of porokeratosis of Mibelli with annular centrally atrophic plaques with raised margins showing the typical ridge (Figures 1 and 2). A few cases of linear arrangement of lesions have been reported. Kienast and Hoeger in $2009^{18}$ reported a 15 -year-old male with a 2 -year history of multiple erythematous linear atrophic lesions along the dorsum of the penis and prepuce with cornoid lamellae on biopsy. A similar case was reported in a 39-year-old male, which resolved by liquid nitrogen cryotherapy over a 6-month period and without recurrence at 2 years. ${ }^{19}$

Follicular porokeratosis of Mibelli restricted to the genital region has been described. Gu et al, ${ }^{20}$ in their large case series of porokeratosis, described a 35-year-old male with multiple 1-5 mm sized brownish papules along the gluteal folds sparing the anus. Histology showed cornoid lamellae arising from the hair follicles. The first report of follicular porokeratosis, however, was in a 42-year-old male who had follicular porokeratosis in the natal cleft. ${ }^{21}$

Genital porokeratosis is extremely rare in females and no significant familial association has been noted for genital porokeratosis, although familial cases of other types of porokeratosis have been described.

Repeated friction with clothes and scratching may be part of the pathogenesis of genital lesions. Pruritus is common in cases reported from Asia. ${ }^{20}$ Diagnosis is often delayed because of rarity of the condition and is often misdiagnosed as psoriasis, lichen simplex chronicus, hypertrophic lichen planus, tuberculosis of skin and Bowen's disease. Biopsy is diagnostic with the typical cornoid lamella and should be done in any longstanding plaque on the genital region, which does not respond to routine treatment. Like porokeratosis, elsewhere few cornoid lamellae are seen in this form of genital porokeratosis, unlike the multiple cornoid lamellae that have been described in the two other variants of porokeratosis on the genital area, that is, ptychotropic porokeratosis and penoscrotal porokeratosis.

Dermoscopy of lesions of genital porokeratosis shows features typical of porokeratosis, namely, central brown 


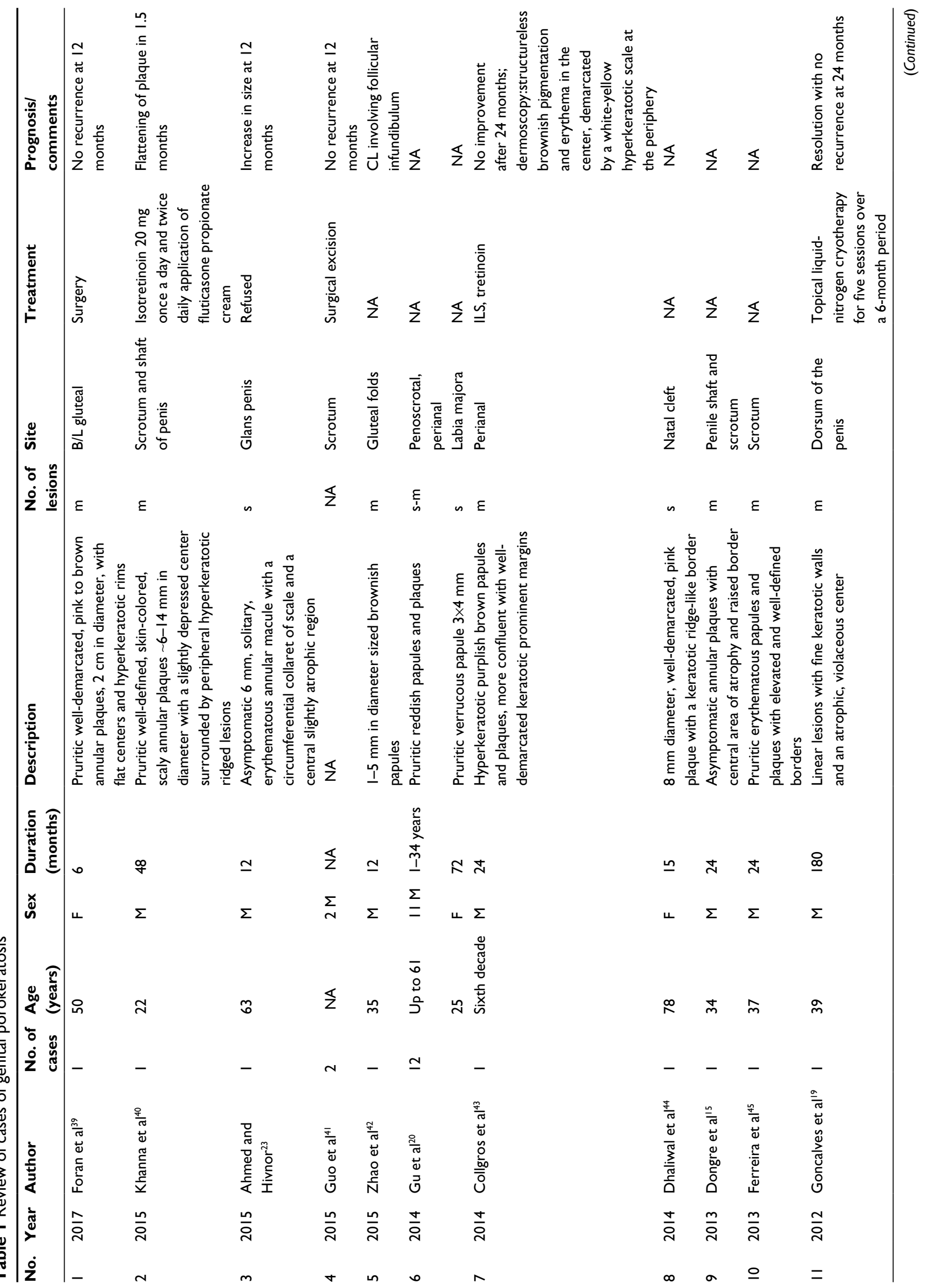




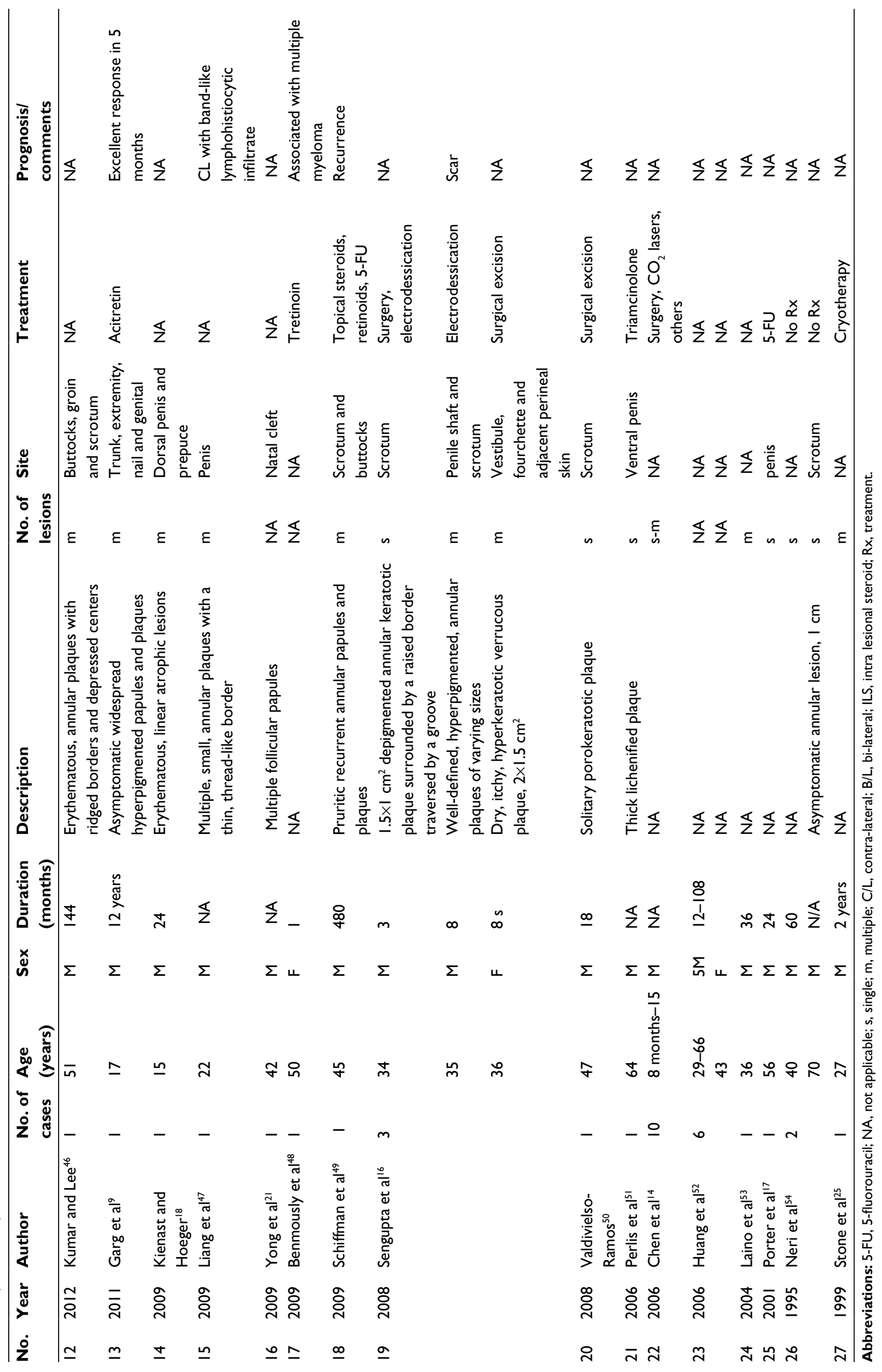




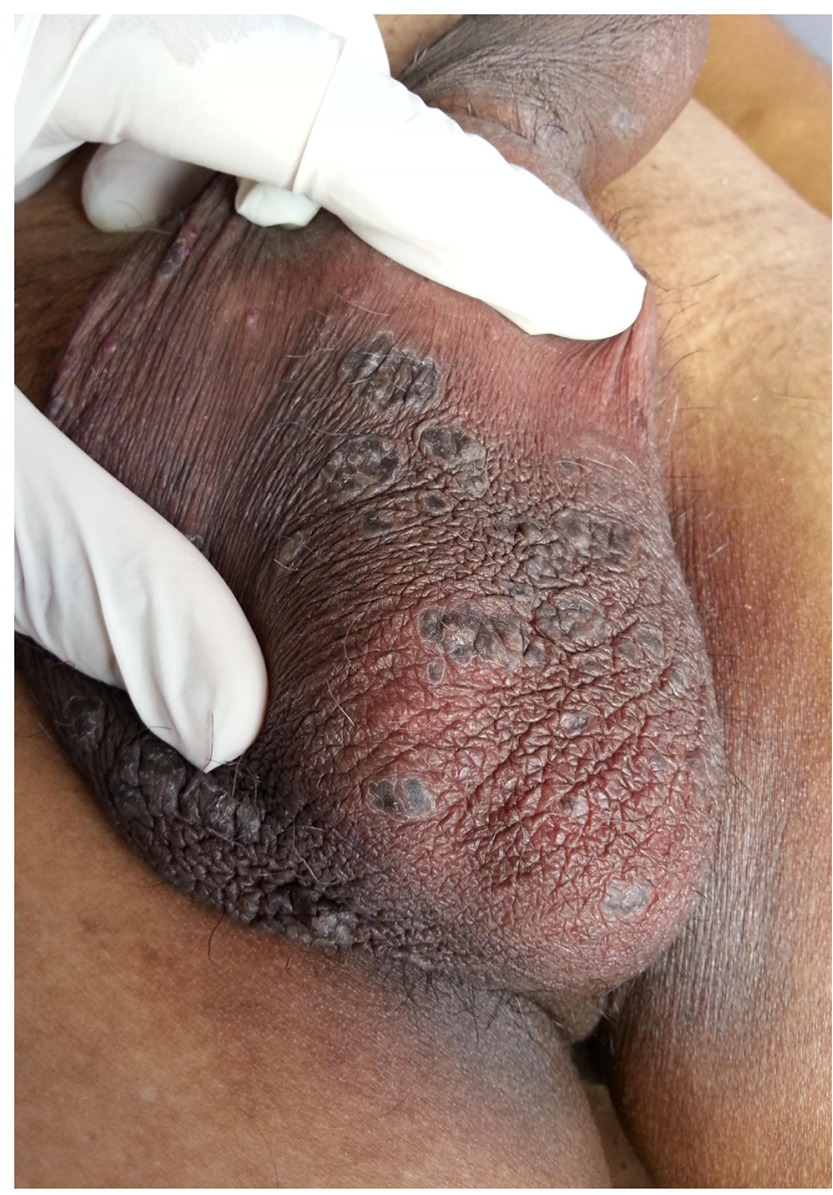

Figure I Classical genital porokeratosis of Mibelli showing multiple annular plaques on the scrotum and penile shaft.

Note: Photo courtesy of K.J. Somaiya Hospital.

pigmentation with many blue-gray dots surrounded by a single hypopigmented band and the "white track" at the periphery. ${ }^{8,22}$

Symptomatic relief from pruritus has been reported by the use of topical steroids and retinoids and 3\% topical diclofenac cream. ${ }^{23}$ However, no therapy, including cryotherapy, $\mathrm{CO}_{2}$ laser, oral retinoids, calcipotriol, 5-fluorouracil or imiquimod, has given lasting benefit.

\section{Ptychotropic porokeratosis}

Table 2 presents a review of cases of ptychotropic porokeratosis.

Lucker et $\mathrm{al}^{24}$ in 1995 were the first to use the term "porokeratosis ptychotropica" derived from Greek ptyche (fold) and trope (turning) to describe the flexural location of this condition. Their patient was a 34-year-old man who had a 9-year history of a pruritic plaque localized to the natal cleft. A similar case was described by Stone et al in $1999^{25}$ in a 32-year-old man with a 13-year history of pruritic lesions confined to the natal cleft. They named it "perianal inflammatory verrucous porokeratosis."

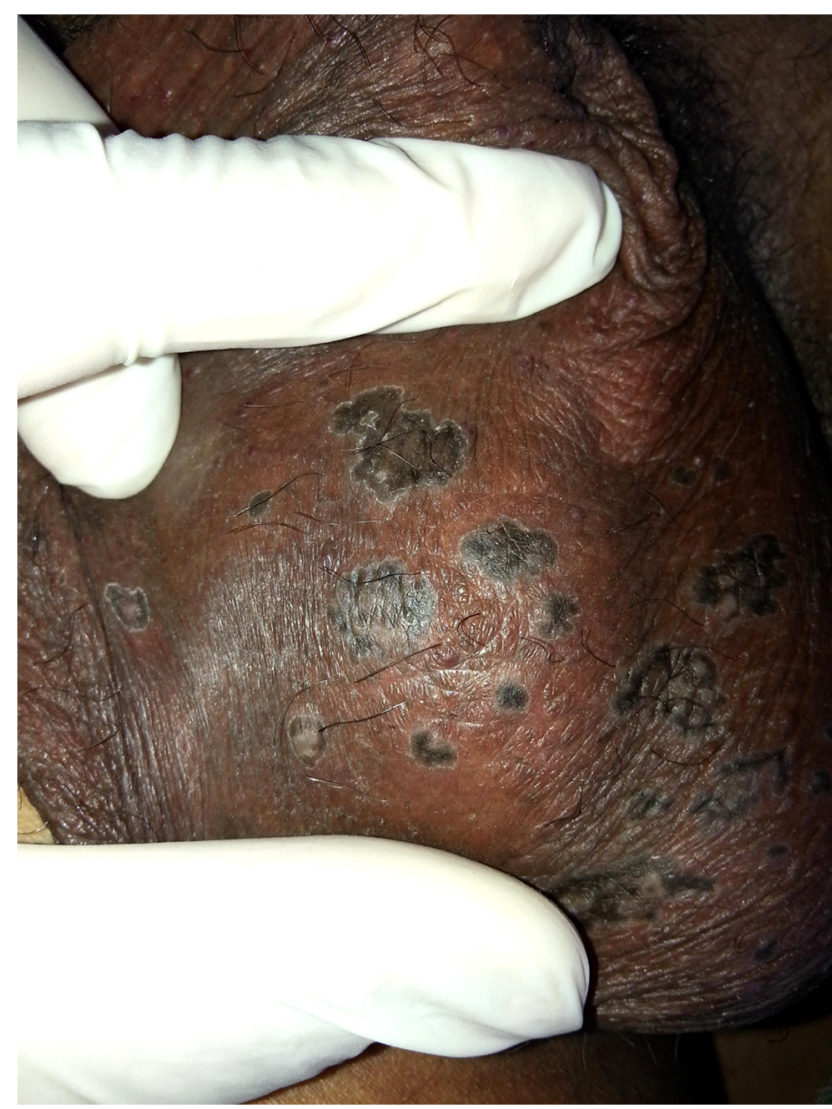

Figure 2 Porokeratosis of Mibelli on the scrotum showing the peripheral ridge that appears hypopigmented and completely surrounds the pigmented annular plaques. Note: Photo courtesy of K.J. Somaiya Hospital.

Ptychotropic porokeratosis (Figure 3) represents a distinct clinical presentation of porokeratosis that presents with slowly enlarging pruritic thick verrucous plaques that involve mainly the natal cleft and the buttocks in a butterfly pattern but have also been described to affect the penis, ${ }^{26}$ scrotum $^{27,28}$ and vulva. In a review of 22 patients, the main regions affected were the buttocks $(36.36 \%)$, genitogluteal region $(31.82 \%)$ and buttocks with involvement of the extremities $(22.7 \%){ }^{28}$

This condition is usually not diagnosed as porokeratosis for several years or even decades because it lacks the classical peripheral ridge and moat appearance, but instead presents as long-standing pruritic verrucous plaques that are misdiagnosed as psoriasis, chronic eczema, lichen simplex chronicus, dermatophytosis or candidiasis. It has also been described as verrucous and hypertrophic porokeratosis. While it is mostly restricted to the genitogluteal region, ptychotropic porokeratosis has been described with lesions elsewhere on the body. Histologically, most case reports have mentioned the presence of multiple cornoid lamellae that differentiate it from the classical porokeratosis of Mibelli. Few cases have been reported to show amyloid deposits in the upper dermis. ${ }^{27}$ 


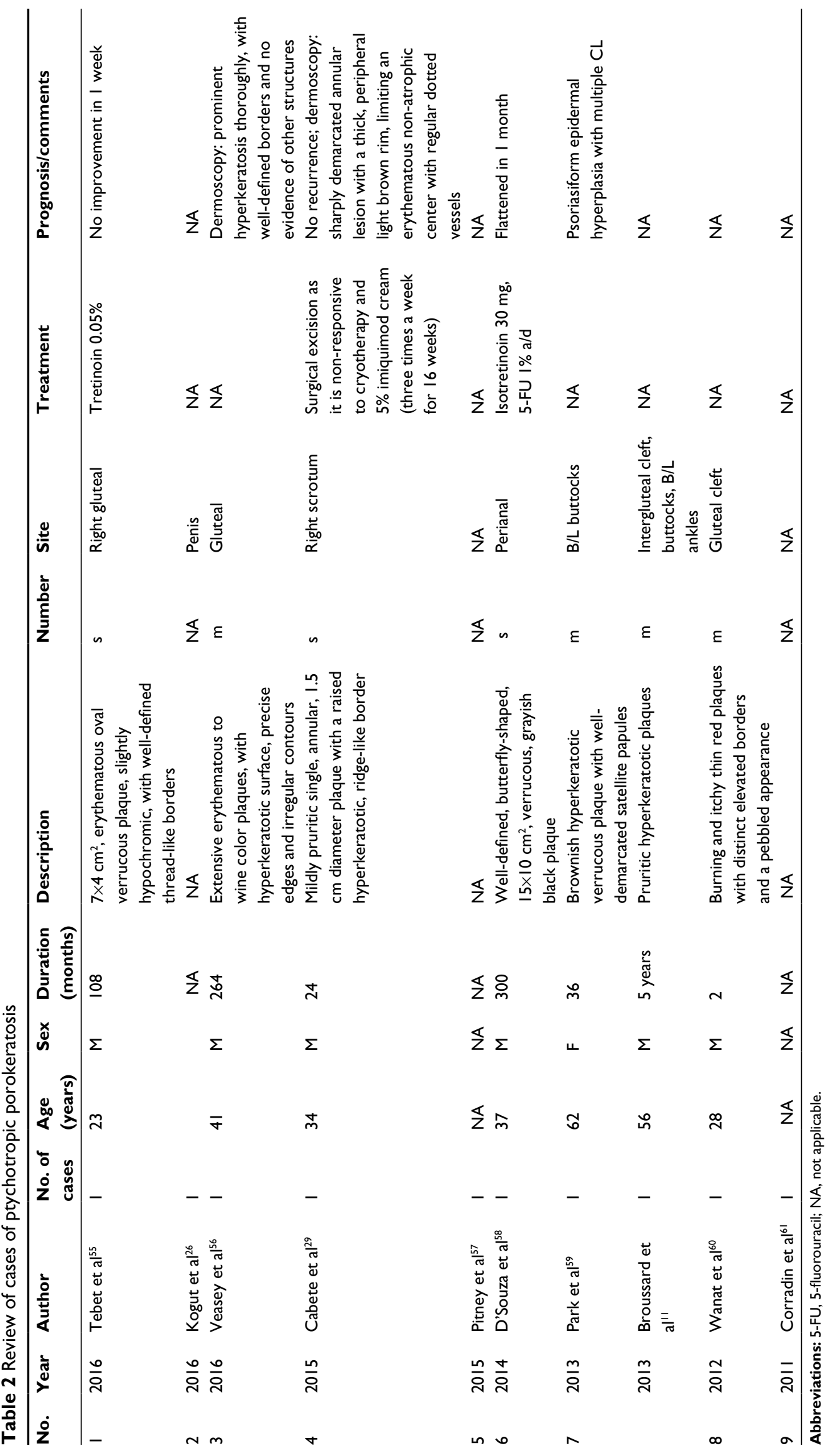




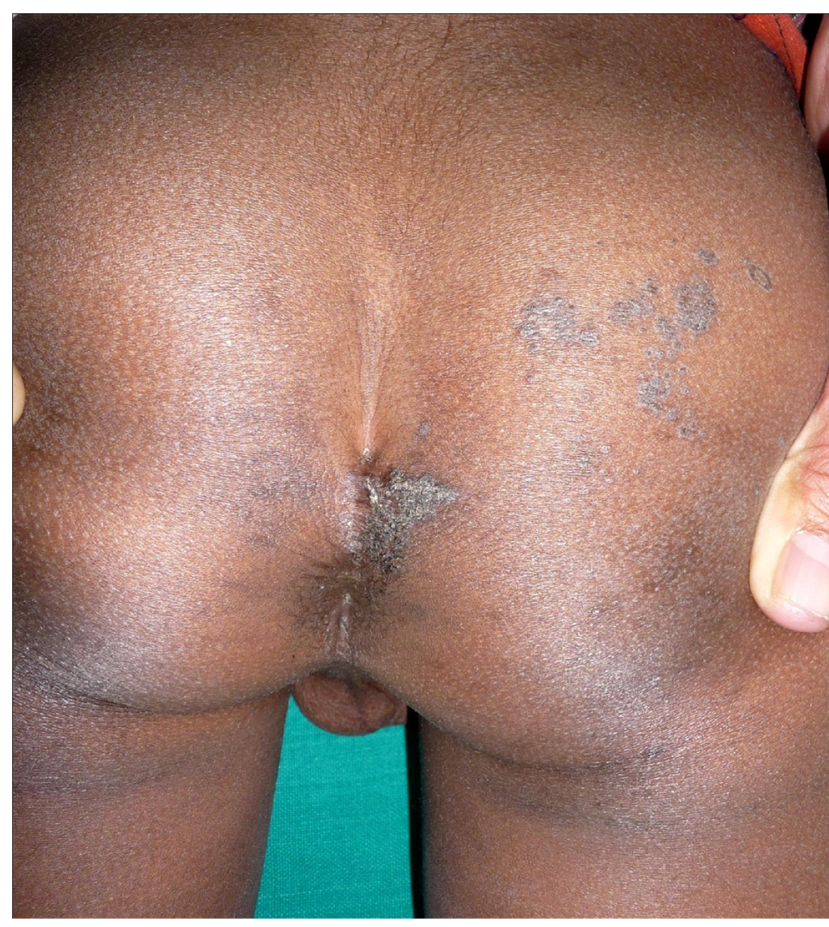

Figure 3 Ptychotropic porokeratosis showing a keratotic plaque on the medial right buttock close to the natal cleft.

Dermoscopic findings have been described as sharply demarcated annular lesions with a thick peripheral brown rim limiting an erythematous non-atrophic center with regular dotted vessels, which differentiates it from other inflammatory conditions such as psoriasis, dermatophytosis and lichen simplex chronicus. ${ }^{29}$

This condition appears to be common in men and of 22 cases reviewed by Takiguchi et al, ${ }^{28} 90 \%$ were males aged between 27 and 84 years. Its etiology is not established, but friction with clothing may be an aggravating factor. Treatment of this condition is disappointing, and response to various treatments is rather poor. The various therapies offered include cryotherapy with liquid nitrogen, 5-fluorouracil, imiquimod, calcipotriol, topical steroids and antifungals, and lasers. The only report of initial successful treatment was in a 25 -year-old man who had a pruritic plaque on the buttock of 8 years duration diagnosed as porokeratosis on histology, which was treated using a dermatome to slice away the superficial tissue; however, there was a subsequent relapse. ${ }^{30}$

\section{Penoscrotal porokeratosis}

Table 3 presents review of cases of penoscrotal porokeratosis.

Penoscrotal porokeratosis appears to be a distinct entity in the family of porokeratotic diseases, described only in young

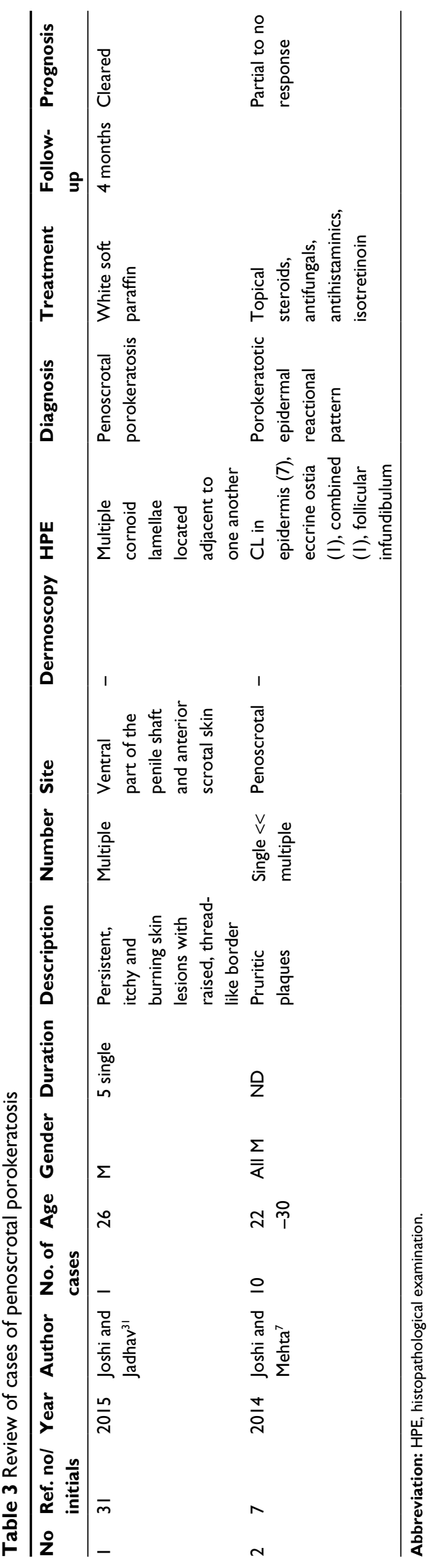


males in their third decade with involvement of the penile shaft and anterior scrotum with severe burning and itching and histologically demonstrating multiple cornoid lamellae. ${ }^{31}$

Repeated minor frictional trauma due to tight-fitting underclothes or a contact reaction to some agent may be the factors in the pathogenesis of these lesions. Joshi and Mehta $^{7}$ described 10 young males who presented with pruritic plaques on the penoscrotal region of several months duration with a clinical appearance not being typical of porokeratosis of Mibelli. They had partly well defined to poorly defined plaques on the ventral surfaces of the penile shaft and the anterior scrotum (Figures 4 and 5).

Biopsy showed multiple cornoid lamellae in nine patients (Figures 6 and 7), which in three cases were seen to arise from eccrine and follicular structures. Clinicopathologically, these cases do not correspond to typical plaque porokeratosis, and they postulated that these cases represent an unusual, hitherto undescribed porokeratotic epidermal reaction pattern with multiple cornoid lamellae.

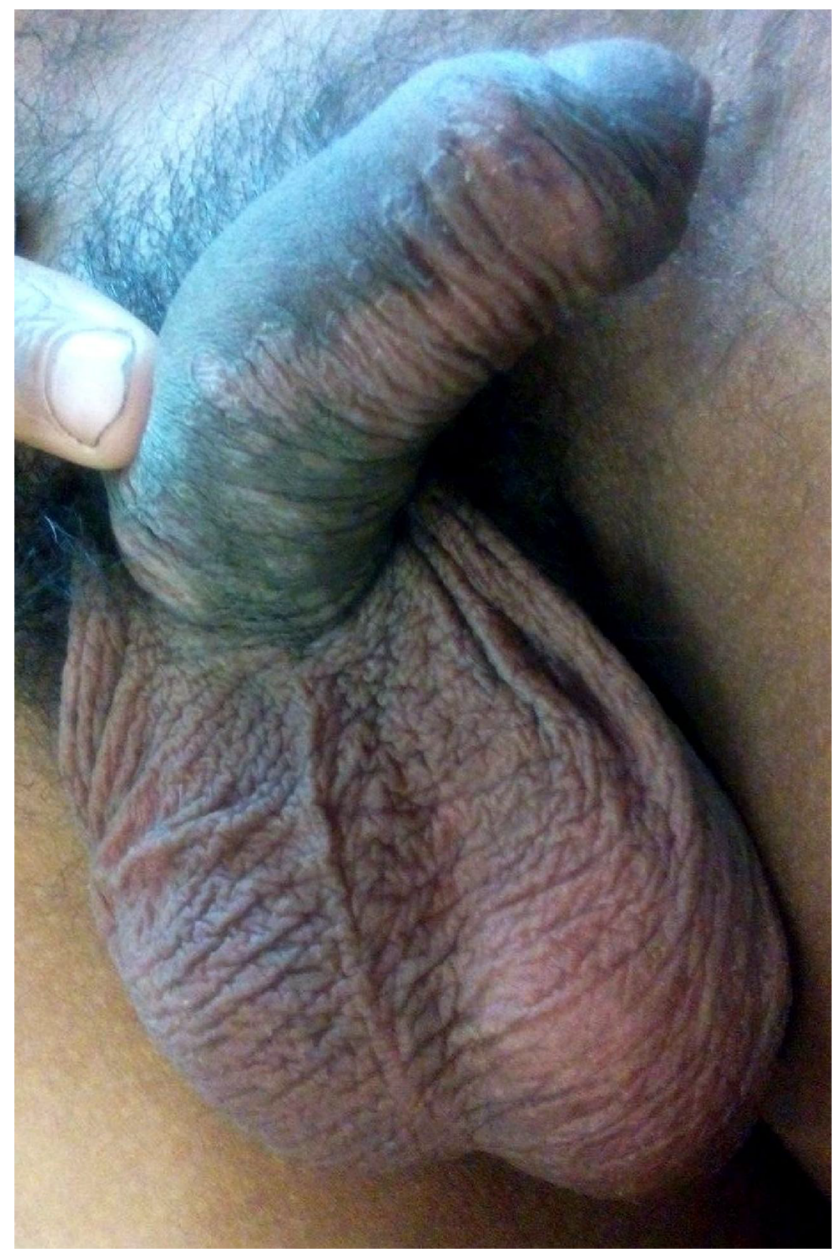

Figure 4 Penoscrotal porokeratosis, annular plaque and small papules on the ventral shaft of penis.

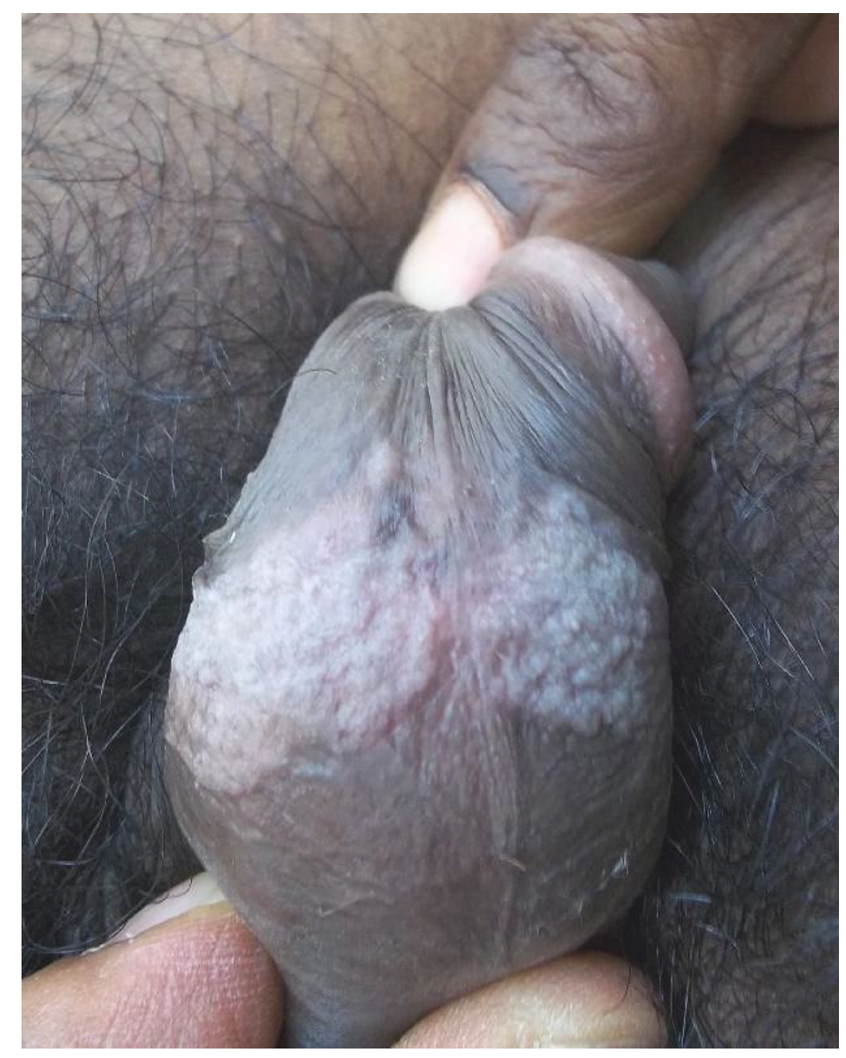

Figure 5 Penoscrotal porokeratosis, hypertrophic verrucous plaques on the anterior scrotum.

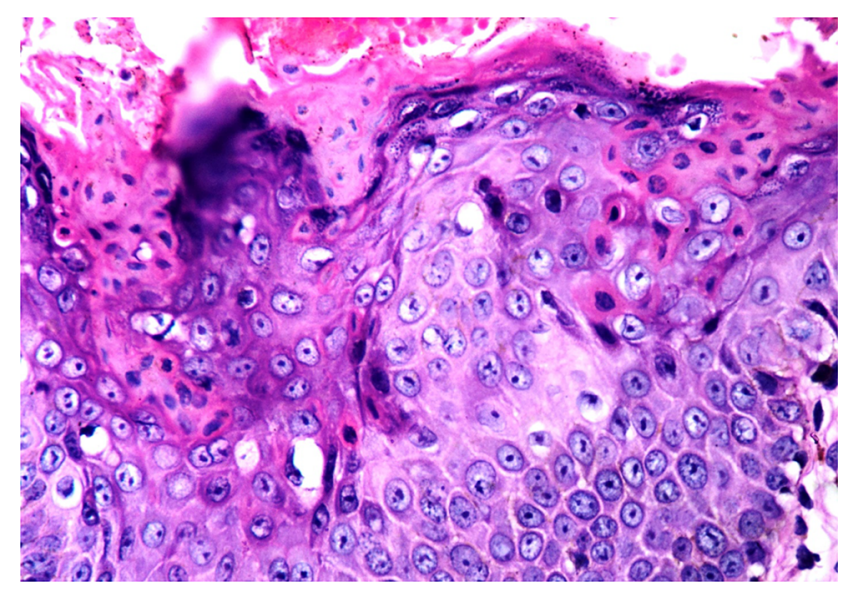

Figure 6 Multiple contiguous cornoid lamellae in penoscrotal porokeratosis. H\&E, $400 \times$.

Treatment with topical steroids and/or antifungals and oral antihistaminics is only partially helpful without any resolution of the condition. Oral isotretinoin showed flattening of the lesions with a decrease in pruritus, but recurrence of symptoms on discontinuation of the medication after 2 months was observed.

The following criteria have been suggested for the diagnosis of penoscrotal porokeratosis. ${ }^{31}$ 


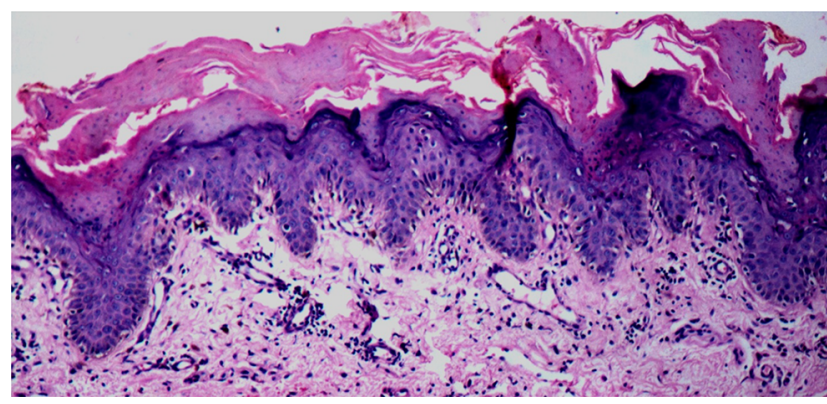

Figure 7 Multiple contiguous cornoid lamellae in penoscrotal porokeratosis. H\&E, 100x.

1. young men in their third decade of life;

2. plaques and diffuse patches with a rough granular surface associated with severe pruritus and burning sensation restricted to the penile shaft and scrotum;

3. histologic findings of multiple contiguous cornoid lamellae, some of which arise from follicular and eccrine structures and

4. a poor response to topical and systemic treatment.

Penoscrotal porokeratosis appears to have a very restricted age involvement with all cases described in males in their 20 s.

\section{Comments}

The etiology and pathogenesis of porokeratosis is not well understood even today, more than a century after its description. Certain mutations have been identified with porokeratosis in some pedigrees, ${ }^{32,33}$ and familial cases have also been reported..$^{34}$ Porokeratosis has been considered to be a premalignant condition, ${ }^{35,36}$ and malignancy had been described in long-standing, large and ulcerative lesions of porokeratosis; $; 7$ however, to date, there has been no report of malignancy developing in genital porokeratosis. A case of 70-year-old male with genito-ano-crural porokeratosis following chronic exposure to benzene, a known carcinogen, has been described. ${ }^{38}$

Unlike porokeratosis elsewhere on the body, genital porokeratosis has been reported to be associated with severe pruritus. Most cases have been described from Asia and the Indian subcontinent, where the hot and humid ambience may be a factor along with friction with tight synthetic clothing.

While all three forms of genital porokeratosis have in common the presence of cornoid lamellae, multiple contiguous cornoid lamellae are seen in both ptychotropic and penoscrotal porokeratosis.

A uniformly poor response to various treatments, topical, systemic and surgical, is seen in all forms of genital porokeratosis, and a reliable modality of therapy for this often distressing condition still awaits elucidation.
In summary, the following can be mentioned:

1. Porokeratosis restricted to the genitogluteal region is an uncommon entity.

2. Clinically, three distinct presentations are seen and may be classified as classical porokeratosis, porokeratosis ptychotropica and penoscrotal porokeratosis.

3. Genitogluteal porokeratosis of all varieties has been described mainly in men with a very restricted age occurrence in penoscrotal porokeratosis.

4. Pruritus that may often be distressing is a common presenting feature as is the chronicity of the disease.

5. The "cornoid lamella" is the common unifying histologic finding in all cases, and multiple cornoid lamellae is the rule in both ptychotropic and penoscrotal porokeratosis.

6. No malignancy has yet been reported in genitogluteal porokeratosis.

7. No satisfactory modality of treatment has yet been described.

\section{Acknowledgments}

The authors thank the following persons for permission to use clinical photographs for this article:

1. Dr Shyam Verma, Consultant dermatologist, Vadodara, India for Figure 3 and;

2. Dr Sheetal Poojary, Professor and Head of Department of Dermatology, K.J. Somaiya Hospital, Mumbai, India for Figures 1 and 2.

\section{Disclosure}

The authors report no conflicts of interest in this work.

\section{References}

1. Neumann I. [Uber eine noch wenig bekannte Hautkrankheit (Dermatitis circumscripta herpetiformis)]. Vierteljahrsschrift fur Dermatologie und Syphilis, Wein. 1875;2:41-52. German.

2. Mibelli V. Contributo alla studio della ipercheratosi dei canali sudoriferi (porokeratosis). G Ital Dermatol Vener Turin. 1893;28:313-355.

3. Requena L, Requena C, Cockeral CJ. Benign epidermal tumors and proliferations. In: Bolognis JL, Jorizzo JL, Schaffer JV, editors. Bolognia Textbook of Dermatology. 4th ed. New York, NY, USA: Elsevier; 2017:1901-1903.

4. Mukhopadhyay AK. Simultaneous occurrence of disseminated superficial, linear and hypertrophic verrucous forms of porokeratosis in a child. Indian J Dermatol Venereol Leprol. 2004;70:364-366.

5. Panth A, Ramam M. Epidermal reaction patterns. Indian J Dermatopathol Diagn Dermatol. 2015;2:1-7.

6. Tran H, Bossenbroek NM, Rosenman K, Meehan SA, Sanchez M, Prystowsky S. Steroid responsive facial eruption with cornoid lamellae-a possible new entity. Dermatol Online J. 2008;14:19.

7. Joshi R, Mehta SG. Pruritic porokeratotic peno-scrotal plaques: porokeratosis or porokeratotic epidermal reaction pattern? A report of 10 cases. Indian J Dermatol Venereol Leprol. 2014;80:24-28. 
8. Hayashi Y, Ozeki M, Ishizaki S, et al. Inguinal porokeratosis in a Japanese man. Dermatol Pract Concept. 2013;3:29-31.

9. Garg T, Ramchander, Varghese B, Barara M, Nangia A. Generalized linear porokeratosis: a rare entity with excellent response to acitretin. Dermatol Online J. 2011;17:3.

10. Watanabe T, Murakami T, Okochi H, Kikuchi K, Furue M. Ulcerative porokeratosis. Dermatology. 1998;196:256-259.

11. Broussard KC, Boyd A, Gloeckner Powers J. Thick intergluteal cleft and lower extremity plaques. JAMA Dermatol. 2013;149:1099-1100.

12. Vij A, Doherty SD, LeLeux TM, Hsu S. Disseminated porokeratosis of Mibelli: a case report. Dermatol Online J. 2010;16:12.

13. Helfman RJ, Poulos EG. Reticulated porokeratosis: an unique variant of porokeratosis. Arch Dermatol. 1985;121:1542-1543.

14. Chen TJ, Chou YC, Chen CH, Kuo TT, Hong HS. Genital porokeratosis: a series of 10 patients and review of the literature. $\mathrm{Br} J$ Dermatol. 2006; $155: 325-329$.

15. Dongre A, Adhe V, Sanghavi S. Genital porokeratosis: a rare entity. Indian J Dermatol. 2013;58:81.

16. Sengupta S, Das JK, Gangopadhyay A. Porokeratosis confined to the genital area: a report of three cases. Indian J Dermatol Venereol Leprol. 2008;74:80.

17. Porter WM, H. Du P Menage, Philip G, Bunker CB. Porokeratosis of the penis. Br J Dermatol. 2001;144:643-644.

18. Kienast AK, Hoeger PH. Penile linear porokeratosis in a child: a case report. Pediatric Dermatol. 2009;26:216-217.

19. Goncalves SVCB, Valente NYS, Oliveira JV Jr, Paiva DL. Case for diagnosis. Linear porokeratosis of the genital area-case report. An Bras Dermatol. 2012;87:489-490.

20. Gu CY, Zhang CF, Chen LJ, Xiang LH, Zheng ZZ. Clinical analysis and etiology of porokeratosis. Exp Ther Med. 2014;8:737-741.

21. Yong AS, Singh M, Goulding JM, Swale VJ. Follicular porokeratosis of Mibelli on the buttocks. Clin Exp Dermatol. 2009;34:43-45.

22. Delfino M, Argenziano G, Nino M. Dermoscopy for the diagnosis of porokeratosis. J Eur Acad Dermatol Venereol. 2004;18:194-195.

23. Ahmed A, Hivnor C. A case of genital porokeratosis and review of literature. Indian J Dermatol. 2015;60:217.

24. Lucker GP, Happle R, Steijlen PM. An unusual case of porokeratosis involving the natal cleft: porokeratosis ptychotropica? Br J Dermatol. 1995;132:150-151.

25. Stone N, Ratnavel R, Wilkinson JD. Bilateral perianal inflammatory verrucous porokeratosis (porokeratosis ptychotropica). BrJ Dermatol. 1999;140:553e5.

26. Kogut M, Schiller M, Hadaschik E, Enk A, Haenssle HA. Porokeratosis ptychotropica involving the glans penis: a unique case of this rare condition. JDDG. 2016;14(2):181-183.

27. Yu YF, Wu YH. Verrucous porokeratosis (porokeratosis ptychotropica) with dermal amyloid deposits. Dermatol Sin. 2013;31:145-148.

28. Takiguchi RH, White KP, White CR Jr, Simpson EL. Verrucous porokeratosis of the gluteal cleft (porokeratosis ptychotropica): a rare disorder easily misdiagnosed. J Cutan Pathol. 2010;37:802-807.

29. Cabete J, Fidalgo A, Lencastre A, Diamantino F, Joao A. Porokeratosis ptychotropica of the scrotum: dermoscopic evaluation of an atypical presentation. An Bras Dermatol. 2015;90:S191-S193.

30. Scheiba N, Enk A, Proske S, Hartschuh W. Porokeratosis ptychotropica: successful treatment with the dermatome. Dermatol Surg. 2010;36:257-260.

31. Joshi R, Jadhav Y. Penoscrotal porokeratosis: a distinct entity. Indian Dermatol Online J. 2015;6:339-341.

32. Zhang Z, Niu Z, Yuan $W$ et al. Fine mapping and identification of a candidate gene $\mathrm{SSH} 1$ in disseminated superficial actinic porokeratosis. Hum Mutat. 2004;24:438.

33. Zhang ZH, Huang W, Niu ZM et al. Two closely linked variations in actin cytoskeleton pathway in a Chinese pedigree with disseminated superficial actinic porokeratosis. J Am Acad Dermatol. 2005;52:972-976.

34. Xia JH, Yang YF, Deng $\mathrm{H}$ et al. Identification of a locus for disseminated superficial actinic porokeratosis at chromosome 12q23.2-24.1.J Invest Dermatol. 2000;114:1071-1074.
35. Otsuka F, Shima A, Ishibashi Y. Porokeratosis as a premalignant condition of the skin. Cytologic demonstration of abnormal DNA ploidy in cells of the epidermis. Cancer. 1989;63:891-896.

36. Magee JW, McCalmont TH, Leboit PE. Overexpression of p53 tumor suppressor protein n porokeratosis. Arch Dermatol. 1994;130: 187-190.

37. Sasson M, Krain AD. Porokeratosis and cutaneous malignancy. A review. Dermatol Surg. 1996;22:339-342.

38. Trcka J, Pettke-Rank CV, Brocker EB, Hamm H. Genitoanocrural porokeratosis following chronic exposure to benzene. Clin Exp Dermatol. 1998;23:28-31.

39. Foran TK, Day T, Bradford J, Scurry J. Genitogluteal porokeratosis in a well woman. J Low Genit Tract Dis. 2017;21(1):e8-e9.

40. Khanna U, D'Souza P, Dhali TK. Genital porokeratosis: a distinct clinical variant? Indian J. Dermatoloy. 2015;60(3):314-315.

41. Guo H, Liu XY, Li B, Gao XH, Chen HD, Li JH. Porokeratosis on the scrotum: two cases. Dermatol Ther. 2015;28(2):83-85.

42. Zhao M, Sanusi T, Zhao Y, Huang C, Chen S. Porokeratosis with follicular involvement: report of three cases and review of literatures. Int J Clin Exp Pathol. 2015;8(4):4248-4252.

43. Collgros H, Iglesias-Sancho M, Aldunce-Soto MJ. Recalcitrant papules and plaques on perianal area and buttocks. JAMA Dermatol. 2014;150(9):1007-1008.

44. Dhaliwal CA, Doherty VR, Biswas A. Pruritic keratotic plaque in the natal cleft. Am J Dermatopathol. 2014;36(4):327, 347.

45. Ferreira FR, Lessa PP, Alvarenga ML. Genitogluteal porokeratosis-case report. An Bras Dermatol. 2013;88(3):438-440.

46. Kumar SS, Lee S. Genitogluteal porokeratosis: an unusual clinical presentation. Australas J Dermatol. 2012;53(2):e36-e39.

47. Liang C, Batra P, Patel R, Kamino H. Genital porokeratosis. Dermatol Online J. 2009;15(8):23.

48. Benmously Mlika R, Kenani N, et al. Localized genital porokeratosis in a female patient with multiple myeloma. $J$ Eur Acad Dermatol Venereol. 2009;23(5):584-585.

49. Schiffman LA, Berry R, Watsky M, Heilman E. Annular patches and plaques on the scrotum and buttocks - quiz case. Arch Dermatol. 2009;145(6):715-720.

50. Valdivielso-Ramos M. Genital porokeratosis. Actas Dermosifiliogr. 2008;99(3):217-220.

51. Perlis C, Robinson-Bostom L, Telang GH, DiGiovanna J. A thick lichenified plaque on the ventral penile shaft. Penile porokeratosis of Mibelli. Arch Dermatol. 2006;142(9):1221-1226.

52. Huang SL, Liu YH, Chen W. Genitogluteal porokeratosis. J Eur Acad Dermatol Venereol. 2006;20(7):899-900.

53. Laino L, Pala S, Innocenzi D, Accappaticcio G, Van Steensel MA. Genital porokeratosis. Eur J Dermatol. 2004;14(3):190-192.

54. Neri I, Marzaduri S, Passarini B, Patrizi A. Genital porokeratosis of Mibelli. Genitourin Med. 1995;71(6):410-411.

55. Tebet AC, Oliveira TG, Oliveira AR, et al. Porokeratosis ptychotropica. An Bras Dermatol. 2016;91(5 Suppl 1):134-136.

56. Veasey JV, Dalapicola MC, Lellis RF, Campaner AB, Manzione Tda S, Rodrigues MC. Porokeratosis ptychotropica: a rare manifestation with typical histological exam. An Bras Dermatol. 2016;91(4):496-498.

57. Pitney L, Weedon D, Pitney M. Porokeratosis ptychotropica: a rare variant with discrete lesions. Australas J Dermatol. 2015;56(1): e28-e29.

58. D'Souza P, Dhali TK, Arora S, Gupta H, Khanna U. Porokeratosis ptychotropica: a rare variant of porokeratosis. Dermatol Online J. 2014; 20(6).

59. Park JS, Kim IY, Chae IS, Ko DK, Chung H. A brownish verrucous plaque on the intergluteal cleft: porokeratosis ptychotropica. Acta Derm Venereol. 2013;93(2):254-255.

60. Wanat KA, Gormley RH, Bennett DD, Kovarik CL. Genitogluteal porokeratosis involving the scrotum: an unusual presentation of an uncommon disease. J Cutan Pathol. 2012;39(1):72-74.

61. Corradin MT, Giulioni E, Forcione M, et al. Porokeratosis ptychotropica. Eur J Dermatol. 2011;21(3):416-417. 


\section{Publish your work in this journal}

Clinical, Cosmetic and Investigational Dermatology is an international, peer-reviewed, open access, online journal that focuses on the latest clinical and experimental research in all aspects of skin disease and cosmetic interventions. This journal is included on PubMed. The manuscript management system is completely online and includes a very quick and fair peer-review system, which is all easy to use. Visit http://www.dovepress.com/testimonials.php to read real quotes from published authors

Submit your manuscript here: https://www.dovepress.com/clinical-cosmetic-and-investigational-dermatology-journal 